\title{
Communication Education
}

\section{"You're doing great. Keep doing what you're doing": socially supportive communication during first-generation college students' socialization}

Angela N. Gist-Mackey, Marissa L. Wiley \& Joseph Erba

To cite this article: Angela N. Gist-Mackey, Marissa L. Wiley \& Joseph Erba (2017): "You're doing great. Keep doing what you're doing": socially supportive communication during first-generation college students' socialization, Communication Education, DOI: 10.1080/03634523.2017.1390590

To link to this article: http://dx.doi.org/10.1080/03634523.2017.1390590

曲 Published online: 06 Nov 2017.

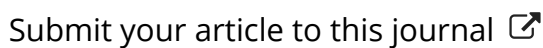

Q View related articles ¿

View Crossmark data ¿ 


\title{
"You're doing great. Keep doing what you're doing": socially supportive communication during first-generation college students' socialization
}

\author{
Angela N. Gist-Mackey (1D) ${ }^{a}$, Marissa L. Wiley (1D ${ }^{a}$ and Joseph Erba ${ }^{b}$ \\ ${ }^{a}$ Department of Communication Studies, University of Kansas, Lawrence, Kansas, USA; ${ }^{b}$ William Allen White \\ School of Journalism and Mass Communication, University of Kansas, Lawrence, Kansas, USA
}

\begin{abstract}
The experiences of first-generation college students (FGCS) are marked by high levels of stress and uncertainty as they navigate the transition to college. This study uses the organizational assimilation model to explore FGCS' transition to college by temporally analyzing multiple sources and types of socially supportive communication found in interviews with 28 FGCS in their first semester at a four-year university. Findings suggest that during anticipatory socialization, FGCS primarily engaged in informational and instrumental social support interactions; in the encounter phase of socialization, FGCS (while still engaging in informational and instrumental support interactions) also engaged in appraisal and emotional support interactions. Findings also illuminate the ways in which FGCS embodied the role of pioneers, even early in the socialization process, suggesting important implications for their role not only as receivers of social support, but as agents of social support.
\end{abstract}

\section{ARTICLE HISTORY}

Received 7 June 2017

Accepted 6 October 2017

\section{KEYWORDS}

first-generation college students; social support; organizational assimilation; college experiences; socialization

Yeah, being a first-generation student is kind of hard because you don't know. I have a friend whose parents went to college, and if they have a question they'll go ask, "Hey, Dad, what should I do about this? Hey, Mom, what should I do about this?" But me, I don't have that ... connection.

$$
\text { -James, Aerospace Engineering Major }
$$

As James illustrated in the excerpt above, the transition to college is filled with uncertainty and a need for guidance and support. When first-year students transition into college, they typically experience challenges with academics, relationships, work, finances, and decision-making, among other difficulties (Nazione et al., 2011). Transitioning from high school to college requires students to experience a "secondary socialization" into their new student roles and environments, a process that can affect their capabilities to adjust (Staton, 1990). While the transition into college can be tough for all first-year college students, the specific circumstances surrounding FGCS (students whose parents did not graduate from postsecondary institutions of education ${ }^{1}$ ) can make this already-difficult transition more uncertain or stressful. 
FGCS account for roughly one-third of all U.S. college students entering college each year (Cardoza, 2016). However, being an FGCS has been cited as a predictor of higher education failure, as FGCS are more likely to be academically underprepared, less likely to seek support sources, and more likely to engage in paid labor while attending school (First Generation Foundation, 2013). Being a first-generation student represents one of the main barriers that keep college students from graduating, along with working more than 30 hours per week and being financially emancipated (Fischer, 2007; Kuh, Kinzie, Buckley, Bridges, \& Hayek, 2007). Academic success of students who face these barriers relies heavily on support programs that universities offer (Kuh, 2016). In a comparative analysis of FGCS and multigeneration college students, researchers found FGCS reported less social support from family and friends, less life satisfaction, and more depression (Jenkins, Belanger, Connally, Boals, \& Duron, 2013). Thus, as FGCS are socialized into college, they likely face multifaceted needs for social support.

Organizational assimilation scholarship documents a four-phase process of socialization for new organizational members: (1) anticipatory socialization, (2) encounter, (3) metamorphosis, and (4) exit (Jablin, 1987, 2001; Kramer, 2010). We apply this fourphase process to explore the ways in which FGCS perceive social support interactions during the early stages of their socialization into university life. Using the organizational socialization theoretical framework (Jablin, 1987; Kramer, 2010), this study focuses particularly on the social support interactions that characterize early socialization. These early stages are arguably the most important for FGCS, since FGCS tend to have higher attrition rates (Postsecondary National Policy Institute, 2016). For this reason, it is crucial to explore those phases where social support could make a difference (and keep students in school). Much of the literature about FGCS focuses on formal programs as support (e.g., Farmer-Hinton \& Adams, 2006; Inkelas, Daver, Vogt, \& Leonard, 2007). We aim to extend this literature using an in-depth qualitative approach that explores the (in)formal social support interactions FGCS engage in as they prepare for and navigate their transition to college. The results of this study may help faculty and administration maximize formal and informal social support and, thus, lead to a more student-ready campus that "strategically and holistically advances student success, and works tirelessly to educate all students for civic and economic participation in a global, interconnected society" (McNair, Albertine, Cooper, McDonald, \& Major, 2016, p. 5).

\section{First-generation college student experiences}

Most scholarship pertaining to FGCS has focused on analyzing the successes and failures of formal efforts adopted by educational institutions and organizations who have served underrepresented populations (Farmer-Hinton \& Adams, 2006; Ghazzawi \& Jagannathan, 2011; Grant-Vallone, Reid, Umali, \& Pohlert, 2003; Inkelas et al., 2007). For example, Grant-Vallone et al. (2003) researched multifaceted university programs tailored to FGCS and/or students who were financially disadvantaged. Students who more frequently used these programs reported higher levels of social adjustment (Grant-Vallone et al., 2003). McKay and Estrella (2008) identified service learning as an effective method to build relationships with faculty and facilitate academic and social integration. Wang (2014) used transition theory to analyze turning points in pedagogical and interpersonal relationships between FGCS and teachers. In sum, this literature points to the importance 
of formal programs and relationships as resources that facilitate FGCS retention and graduation. In order for FGCS to thrive in higher education, their networks likely need to incorporate diverse sources and types of social support.

\section{Identity \& FGCS}

We know from literature that FGCS' identities play a significant role as they navigate their transitions between home and college experiences (Orbe, 1998). In a series of studies, Orbe and Groscurth (Orbe, 2004, 2008; Orbe \& Groscurth, 2004) explicated the communicative identity negotiations of FGCS, revealing distinct communication behaviors between campus and home and the reality that FGCS lack a significant sense of community. This perceived lack of community is another reason why studying social support is critical for FGCS.

Although FGCS share commonalities in identity in terms of their parents' educational status, they are a heterogeneous group as to other variables such as race/ethnicity, social class, siblings' education, and parents' occupation. Research has illustrated, however, some relationships among race/ethnicity, social class, and first-generation status. African Americans and Latina/os are more likely to be first-generation students than whites, Asians, or multiracial students (Balemian \& Feng, 2013; Fischer, 2007). According to the U.S. Department of Education, African American and Latina/o students are less likely to be enrolled in institutions of higher education (2016a), more likely to receive financial aid (2015), and less likely to graduate (2016b) than their peers from other racial/ethnic groups.

For those FGCS who are also part of other underrepresented groups, there are additional challenges. For instance, minority students usually feel they are treated as spokespersons for all people from their race/ethnicity and that their presence in classrooms makes them exceptions to the stereotypical views their white peers and professors have of them (Davis et al., 2004; Frank, 2003; Wasburn-Moses, 2007). Social support could mitigate some negative experiences for FGCS in marginalized groups and for FGCS in general.

\section{Social support and FGCS}

Burleson and MacGeorge (2002) conceptualized social support as "supportive communication: verbal (and nonverbal) behaviors intended to provide or seek help" (p. 384). There is a wealth of evidence suggesting the importance of these social support behaviors for college students. Napoli and Wortman (1998) reported that when college students engage in higher levels of social support with peers and family, they also have increased satisfaction in college and have better overall social and academic adjustment and integration. Specifically, research suggests social support for FGCS is related to positive outcomes: increased well-being (Braithwaite \& Eckstein, 2003), self-esteem (Grant-Vallone et al., 2003) and self-efficacy (Gibbons \& Borders, 2010). Additionally, Clauss-Ehlers and Wibrowski (2007) posited that social support is a key factor in helping FGCS to cope with the stress of college and to become resilient. Although there are a number of typologies classifying social support (e.g., Cutrona, 1996; House, 1981; Leach \& Braithwaite, 1996), we use House's (1981) typology because it was developed in reference to organizational contexts. Given colleges and universities are types of organizational contexts, this typology provides a relevant framework for understanding social support in the university context. 
House's (1981) typology included four types of social support: informational, emotional, appraisal, and instrumental. Informational support is defined as helpful information or advice that alleviates stress of certain issues, is useful in addressing challenges (House, 1981), and can serve to reduce uncertainty and increase a sense of control (Malecki \& Demaray, 2003). Emotional support includes expressions of caring, concern, love, or trust (House, 1981). Appraisal support provides useful feedback for evaluation and can include social comparison (House, 1981). Instrumental support accounts for aid that is tangible or material, like time, money, or physical assistance (House, 1981). To better understand the socialization experiences of FGCS, this study explored the sources and types of support sought, received, and provided during early stages of socialization.

\section{Organizational assimilation and student socialization}

Jablin $(1987,2001)$ developed a theoretical model of organizational assimilation processes that holistically accounts for the experiences before, during, and after individuals join any organization. Phases of organizational assimilation include anticipatory socialization, encounter, metamorphosis, and exit (Jablin, 1987, 2001; Kramer, 2010). In the anticipatory socialization phase, FGCS gain exposure to and learn about the university (Kramer, 2010). This is typically facilitated by gaining information from media, family, peers, prior experience, and education (Jablin, 2001). In this phase, students anticipate what college life will be like and learn about college in myriad ways. FGCS' transition to college can be facilitated by college preparedness programs in high school (Stephan \& Rosenbaum, 2013), similar to that of multigeneration students. However, the anticipatory socialization phase differs for FGCS when compared with multigeneration students since they likely cannot receive guidance about college from parents/guardians during this time (i.e., how to navigate bureaucratic processes or structures, or what university jargon means, etc.). The information gathered during anticipatory socialization feeds into the encounter phase.

Once FGCS enter college, they transition into the encounter phase of socialization, which is marked by high levels of ambiguity, uncertainty, anxiety, and informationseeking (Kramer, 2010). As first-year students grapple with the unknown territory of higher education, they undergo "occupational or role socialization," learning to be a student in a particular institution, and "organizational or school socialization," learning the norms and behaviors of the institution (Staton, 1990). Additionally, since the encounter phase is filled with uncertainty, new organizational members seek information communicatively (Kramer, 2010; Miller \& Jablin, 1991). Information-seeking typically leads to sensemaking processes (Weick, 1995), where new members assign meaning to unfamiliar roles and environments (Kramer, 2010). Students' transition into college is often facilitated by membership in student groups and participation in activities (Pike, Kuh, \& McCormick, 2011), as well as academic support and learning opportunities from their institution (Kinzie, Gonyea, Shoup, \& Kuh, 2008). For instance, FGCS in living-learning programs reported better transitions into college compared with FGCS in traditional residence halls (Inkelas et al., 2007). Similarly, Pike and Kuh (2005) found that FGCS who lived in a residence hall reported increased learning outcomes than those who lived off campus. This sort of engagement in socially supportive cocurricular spaces and activities can help FGCS feel like they belong on campuses and that their classes are relevant to their future goals (Kuh, 2016; Pike \& Kuh, 2005). 
Faculty interactions are also a vital component during the encounter phase (Inkelas et al., 2007), within and outside the classroom. In particular, out-of-classroom communication (OCC) with instructors can boost students' development with academic skills, particularly for students of color (Kuh, 1995). OCC can range from structured to unstructured interactions between teachers and students and has been found to have positive associations with students' self-regulated and peer learning (Sidelinger, Bolen, McMullen, \& Nyeste, 2015). However, FGCS may perceive talking to instructors as "an unnerving activity ... perhaps causing them to ultimately forgo (abandon) the opportunities to communicate with faculty one on one" (Padgett et al., 2010, p. 109). While interacting with faculty may be both daunting and restricted by faculty schedules, academic support can also come from other students and therefore "take place anywhere and at anytime" (Thompson, 2008, p. 140).

\section{Research questions}

As illustrated in the literature, student socialization is a complex and interactive process in which students are "dynamic individuals engaged in the formation of their own roles as students" (Staton, 1990, p. 9). Arguably, the complexity of FGCS socialization suggests the importance of socially supportive communication for these students, yet the issues surrounding social support are potentially complicated for this group of students. First, studies examining social support of FGCS have revealed multiple sources of support, largely including family (Lancaster, 2010), peers (Purswell, Yazedjian, \& Toews, 2009), and institutional programs (Farmer-Hinton \& Adams, 2006; Ghazzawi \& Jagannathan, 2011; Grant-Vallone et al., 2003; Inkelas et al., 2007). Our study aims to explore these and other sources, from the perspective of FGCSs. Second, we acknowledge FGCS are in a unique position to provide social support since scholars point to FGCS as role models (Orbe, 2008). Our study considers the support FGCS perceive they provide. Third, we explore the temporality of social support for FGCS by examining FGCS perceptions of the first two phases of socialization (anticipatory socialization and encounter). We aim to explicate the role of various types of social support as an integral component of socialization processes, including support from both formal institutional and informal noninstitutional sources. Finally, we foreground FGCS voices, asking them to describe and delineate the social support they have received and given. To these ends, this project was guided by these research questions:

RQ1: How do FGCS engage in social support interactions during the anticipatory socialization phase?

RQ2: How do FGCS engage in social support interactions during the encounter phase?

RQ3: How, if at all, do FGCS enact the role of providing social support?

\section{Methods}

To explore the research questions, we employed a qualitative interpretive methodology. We collected data by conducting in-depth, in-person, semistructured interviews with FGCS during their first semester of college at a large, predominantly white public state 
university located in the Midwest. The university admits roughly 570 FGCS annually with an estimated undergraduate population of 18,750 students. Based on university self-report data for race and ethnicity, the student population is approximately $70.6 \%$ white, $7.6 \%$ Hispanic, $4.9 \%$ two or more races, $4.5 \%$ Asian, $4.1 \%$ black, $0.41 \%$ American Indian/ Alaskan Native, and $0.03 \%$ Pacific Islander/Native Hawaiian. There were approximately $7.5 \%$ of students whose race/ethnicity was either unreported or listed as an undocumented nonresident.

We recruited first-year, first-generation participants using purposive sampling from introductory classes. Instructors announced the study and circulated sign-up sheets. A total of 48 students signed up to participate, and interviews were successfully scheduled and conducted with 28 volunteers. After providing consent, participants completed a demographic survey. All participants self-reported their ages as 18 or 19 years old and self-identified as cisgender. We used pseudonyms, which align with self-reported gender, to ethically protect confidentiality (Tracy, 2010). See Appendix A for a table of participants' demographic characteristics and family attributes.

Participants received a $\$ 15$ MasterCard $^{\circledR}$ gift card as incentive. Interviews were conducted in private spaces on campus and ranged from 33 to 105 minutes in duration, averaging 70 minutes. Interview questions covered personal background, college expectations and experiences, media, and identity. Interviewers asked questions relating to college, such as: Where did you obtain information about selecting and applying to college? What has being a college student been like so far? Has anything been particularly confusing to you as a college student? How you think going to college will impact your life? Interviewers probed compelling responses. $^{2}$

Interview data were audio-recorded, transcribed, de-identified and reconciled. Data resulted in approximately 840 single-spaced pages. We used ATLAS.ti for data management and analysis. We used a combination of open coding, identifying relevant themes line by line, and focused coding, searching for specific codes to group them into categories (Charmaz, 2006; Emerson, Fretz, \& Shaw, 1995). We then employed theoretical coding to gain further insight about participants' college transition and socialization (Emerson et al., 1995). Theoretical coding helped make sense of participants' responses by exploring larger connections and generating more conceptual categories linked to theories beyond the main tenets of our existing frameworks. The research team met throughout data collection and analysis to compare notes and discuss the emergent findings. Once we identified themes, we examined what phase of socialization FGCS discussed (anticipatory socialization or encounter), and whether students were discussing seeking, receiving or providing support (or anticipating their future ability to provide support).

We used two practices of verification to ensure the trustworthiness of our process (Creswell, 2007). ${ }^{3}$ We first conducted a member check, taking findings to a smaller subset of participants for confirmation or revision. All four participants who reviewed these findings agreed they authentically represented their experiences as FGCS. They were given a chance to offer suggestions for revision, and all said that the findings were satisfactory. We also conducted peer debriefing, a process of having two third-party scholars, one with expertise in socialization and one with expertise in social support, read and vet the study. One of these scholars was an FGCS. We incorporated their recommendations into the manuscript. 


\section{Findings}

Findings provide insight into the role of socially supportive communication behaviors during the anticipatory and encounter phases of socialization for FGCS. It is important to note that, while our sample was diverse in regard to racial/ethnic identities, home town of participants, academic majors, parental professions, and family income levels, we did not see any particular trends in the data vis-à-vis college socialization or social support that seemed to differ based on these characteristics. ${ }^{4}$ That is, students' identity as FGCS emerged as more salient than their other identities in answering our questions about college transition and socialization, as demonstrated by the many occurrences in which the main themes that emerged from participants' answers revolved around being the first to go to college or having to figure college out on their own.

\section{Social support interactions in anticipatory socialization (RQ1)}

During anticipatory socialization, FGCS engaged in five kinds of social support interactions: consuming organizationally produced media, engaging social media, seeking trusted sources of information, navigating financial pressures, and managing impressions. While family emerged as a dominant source of both informational and instrumental social support, it was the only source in the anticipatory phase that included both supportive and unsupportive messages. Only informational and instrumental support types emerged during this phase.

\section{Consuming organizationally produced media}

During anticipatory socialization, organizations' recruitment processes typically provide information to prospective organizational members and in turn those prospective members seek information to inform decision-making processes about joining an organization (Kramer, 2010). Media produced by educational institutions was a dominant source of information. For example, Ashley said, "Media was my whole experience with college because I didn't have a person who went to college to ask these questions to." As an FGCS, she purposefully relied on media.

University e-mails and websites, Google searches, and College Board were mentioned as online media used for information. For example, Patricia explained, "I remembered typing in Google like, '[university] facts,' and stuff like that. But I think College Board was the main one that I kind of got all my information for. I trusted it because everyone uses College Board." Patricia perceived this media outlet as a credible source because of its heavy use among others.

Some students sought out media not only to gather information, but also to form impressions about institutions of higher education. Richard explained he examined schools' websites in regard to both "how much information they can give you" and "if it's just like visually pleasing. ... Like some school's websites, I looked at it and it looks like it was made back in the 80s or something." His response revealed a strategic approach to seeking information.

Media, such as pamphlets, e-mail, and traditional mail provided information regarding application processes, financial aid, campus life, and resources. For example, John stated, "The way [this university] just constantly e-mailed me, constantly sent me letters in the 
mail they just [pause] I really felt that support. Like I, I just [pause] knew ... that [this university] actually had like a good support system ... " John explicitly referenced feeling supported, and he perceived a solid support system because of the information he received. Jessica also mentioned traditional mail that was sent from the university: "A lot of my questions were answered through brochures that they sent in the mail." The direct mail sent to Jessica helped to lower her level of uncertainty about college.

\section{Engaging social media}

In addition to traditional media, many participants described using social media, such as blogs, Facebook, Twitter, Instagram, Yik Yak, and YouTube to receive informational support prior to college. Some participants mentioned following university or college student social media accounts because "That's a good way to get to know more about campus," as Jennifer stated. Thomas said, "I know definitely during the application process, they kept tweeting, 'Application is open July 1st. To learn more about it, click this link."' This information aided Thomas' application submission. Richard also explained his use of social media, "So like my friend ... would post pictures about [this private university] and stuff like that. That's how I got to know more about specific schools before even applying because I would see other people posting about their schools." This impression formation process, supported by the information gleaned from social media, informed students' thinking about their future college life.

FGCS found social media particularly helpful because some of this information was published by other students. Linda explains her reliance on YouTube, revealing, "I did a lot of YouTube videos. They tell you what you to need prepare for your dorm, or how it's going to be, so YouTube is a very big influence on me." Others also used YouTube as a source for informational support. For instance, Matthew stated, "Mostly like, I guess, blogs, I guess. Like people ... like actually talking about experiences and stuff. It's like those videos from YouTube." Hearing from those living collegiate experiences seemed to be important to FGCS. Our participants' reliance on social media could also be connected to their age, as all participants were millennials and thus “digital natives" (Keeter \& Taylor, 2009).

\section{Seeking trusted sources of information}

High school personnel and programs were a dominant source of trusted information for FGCS, which has been documented in scholarship (Stephan \& Rosenbaum, 2013). Many participants in our study mentioned specific authority figures from their high schools as invaluable sources of informational support. When Anthony was asked where he received information about how to apply to college, he replied, "That had to be my high school advisor. I am a first-gen student, so I had absolutely no help from anyone in my family." The inability to seek/receive support from parents/guardians likely increased the salience of high school personnel as a source of social support.

FGCS seemed to find out about all aspects of college selection and application from these authority figures. For example, James said, "Um, my high school counselor ... I would sit with her. She told me everything I needed to know about applying to college, what I need, the FAFSA, about what I need to do, the ACT and all that." James was not alone when he revealed the breadth of information he received from his counselor included details about applications, financial aid, and standardized tests. Jennifer, 
Catherine, Anthony, James, Richard, Linda, Mark, and Mathew, among others, explicitly mentioned similar information received from high school counselors or advisors, revealing high school personnel as a critical source of support to their anticipatory socialization.

FGCS also recalled specific teachers from their high schools who supported their postsecondary educational aspirations. Catherine mentioned she was "really close with my band directors also. So like, I guess I've asked them a lot more questions ... Like, just a random college stuff." Richard mentioned that he "talked to my ROTC" instructor who attended the college he selected. In addition, Michelle revealed that high school teachers "helped me with scholarships and applying" for college admission. High school counselors, advisors, and teachers played an integral role in the support of FGCS. This emergent finding revealed a strong relational dynamic as part of FGCS socially supportive communication behaviors.

Formalized high school preparation was also often referenced as a source of informational support. Matthew explained that during his high school education a "College Go Center" was developed.

They provided a lot of resources ... so like whenever we needed help with applications, scholarships, anything [pause], we went there and they helped us out.... So they gave me plenty of resources like online websites, and that's where I went from there.

Matthew reveals a connection between his secondary educational support from the "College Go Center" and his media consumption. While resources like the "College Go Center" are likely helpful for all prospective college students, it is particularly helpful to have a centralized location for college preparation resources for FGCS. Doing so makes informational support more immediate and accessible. Finding high schools that provided college preparation seemed to be important and intentional for FGCS.

Ashley and Linda, among others, also emphasized how important college resources located at specific high schools were, but so were outside organizations that partnered with local high schools. Stephanie was part of scholarship program sponsored by a local nonprofit organization that provided informational and instrumental support. She explained that

They had um, counselors and ... mentors and stuff like that. They also went to college. So they gave us some pointers and tips.... [They] took us, like, to numerous campus visits and stuff like that. And they, um, always had workshops and stuff for us to go to and how to apply to college.

Finally, although many FGCS in this study identified external trusted sources of information (high school programs, nonprofits, etc.), some identified family members from whom they received social support. FGCS in our study mentioned aunts, cousins, grandparents, siblings as well as parents. For example, Mark shared, "My older brother was a [university] grad and he told me a lot about [this university] and like what was going to go down." Similarly, Paul shared that his sister supported him with information. "Cause she's already been through the whole process, and then graduate school, so I just feel like she knows a lot about it and is able to help me." Paul also shared that his sister was "the one that was helping me out the most with like writing my essays and everything like that." 


\section{Navigating finances}

Participants primarily engaged in instrumental support interactions regarding the financial aspects of college preparation. For example, Richard received funds from his father's G.I. Bill. He stated, "I've been blessed that I could go and use my dad's G.I. Bill to get into college." Jessica also shared how her mom supported her by helping her find sources of financial aid. She explained, "My mom would always look for scholarships. She emailed them to me and I'd work on them when I was in a study hall in high school." This exchange of informational support with her mother helped Jessica remain productive with her application processes for financial aid.

Despite support received, some students expressed frustration with seeking support to navigate their finances. Amanda shared an experience trying to apply for financial aid: "It was such a hassle because getting my dad's information, [pause] he was like, 'I don't know, just go ask your aunt.' I was like, 'You're supposed to know your [tax] information.' It was so difficult trying to get him to give me his information.” For Amanda, in order to obtain financial aid, she first needed to gain information about taxes and the application process. For her, this social support interaction proved frustrating and stressful.

By contrast, some students discussed a more productive partnership with parents where they collaborated to solve problems. FGCS in this study mentioned this type of collaborative problem-solving in relation to financial aid applications. For instance, Robert explained his situation:

My father tried to help me out. He called Sallie Mae and tried to figure out how much they were willing to give me, ... but I didn't really have anyone to talk about what it was. I mean, my parents tried to help me out with actually how much money it was going to be and they'd be like well if you get this much money and then we can put this much money...

In Robert's example, a sense of teamwork emerged where his parents were willing to contribute what could not be provided by student loans. Thomas explained that when he was trying to secure financial aid, he felt overwhelmed. He said, "But the financial aid ... applying for your FAFSA to it and everything, and what fee went with what-that was a lot thrown at me. My mom helped me with that one. We just figured it out together." In some instances, frustration seemed to be mitigated by the supportive interactions with parents. Unfortunately, this was not always the case.

\section{Managing impressions}

Some FGCS in this study disclosed interactions they characterized as unsupportive, which required them to manage impressions. For example, family at times dissuaded prospective FGCS from attending college. Michelle shared, "Everyone's told me, 'I don't know if you can do this.' ... So I think that's important to prove them wrong. Like, 'you might think I couldn't have done this because you couldn't, but I can." Linda's extended family was also unsupportive, "You always have those family members who doubt you, and some of them are like, 'She ain't going to make it that far." Catherine expressed a similar sentiment, "Okay, so I have an aunt that thinks ... it's ridiculous that I'm at [this university]. And she told me." Amanda's father also seemed resistant. She shared, "He didn't even want me to come." Amanda said, "He wasn't very supportive the whole time." Mary shared that she had to justify to her older cousins why she wanted to go to college: 
You have to sit there and explain how you actually have ambitions and goals.... Most of them are like, "Why do you need a degree? A lot of people with degrees don't have a job right after college." I hear that so much. I'm just like, "Well, can I just do me? Can I like try for myself? Can I, like I have the opportunity. Let me, let me experience it.... Um, don't tell me to quit just because it happened to you. That's not going to happen to me just because it happened to you."

Mary's story revealed frustration with her older cousins who questioned her decision. In another example, Christopher seemed motivated by unsupportive interactions:

People who didn't think I was going to rise too much, those are the ones that mainly influence me a lot, like the ones that didn't really have hope, doubted me, because that's when I want to prove them wrong. I want to come back in 20 years and be the successful person that they always said I wouldn't be.

In other examples, Ashley and Lisa also disclosed unsupportive interactions regarding college. As participants described emotionally unsupportive interactions, several affective responses emerged, including motivation, determination, frustration, and discouragement; these were followed by efforts at managing impressions. FGCS' perseverance and resilience not only got them to college, but also manifested after starting.

\section{Social support interactions in encounter (RQ2)}

Once FGCS arrived on campus, new support systems emerged from friends, student peers, residence hall assistants, advisors, mentors, professors, staff, and teaching assistants. Results indicated that FGCS often engaged in informational support interactions; this makes sense given the high levels of uncertainty expected during this phase. At the same time, FGCS also engaged in emotional and appraisal interactions during their first semester. FGCS described engaging in three types of social support interactions: engaging peers, leaning on organizational experts, and attending to affirmation.

\section{Engaging peers}

FGCS often mentioned newly formed friends as their first resource for informational and emotional support interactions. FGCS readily identified these friendships and peer groups as support networks for both academic and social life. For example, when we asked Rebecca about something positive that has happened since she started college, she replied, "The friends that I have made ... the fact that I have a support system." Rebecca's experience with developing friendships was positive overall because it gave her a network of support while beginning her college career. It seemed to be critically important that FGCS had "friends to rely on," as Richard expressed. Matthew revealed a hierarchy of support when we asked him whom he went to for encouragement: "Just need encouragement? First friends, I go to them."

Peer student interactions were typically facilitated through other university connections such as classes or residence halls. For instance, Kevin, mentioned other students in band with him:

The most positive thing I think that's happened to me, um, since I got on this campus is probably just joining the band. ... It's been an adventure and it's just really positive. ... Everybody is like, "Okay well, if you need help I'm here to help you out." 
Having positive student interactions in the university band seems to have set an encouraging tone for Kevin's college career by providing him with a supportive peer network. Mary echoed a similar sentiment regarding support from other students: "My RA is really nice and she's like open to questions.... She always seems to have answers, so I kind of just go to her and we can relate a lot, so that's good." Thomas, Patricia, Christopher, Robert, Richard, and Jennifer, among other students, also mentioned students in their residence halls as sources of social support. While FGCS did not reference these other students as friends specifically, they did often disclose gaining valuable information and support from these peers. Overall, these interactions lead to positive college experiences during the encounter phase for FGCS in this study.

\section{Leaning on organizational experts}

Many participants explicitly recognized university staff members who positively impacted their experiences during the first semester; they gathered information from these staff members on an array of college processes. For example, Patricia disclosed seeking informational support from several sources:

I talked to my advisor. ... I talked to my counselor back home. I also went to one of the financial advisors. ... Um, I think just getting through different perspectives really helped because it made me see everything possible.

Patricia's description shows strategic effort to communicatively solicit information from multiple sources in order to help her "see everything possible."

The most uncertain experience for our FGCS participants was the process of enrolling for classes for their second semester of college. Anthony, Christopher, Jennifer, Jessica, James, Linda, Mary, Michelle, Paul, Patricia, Rebecca, and Robert all explicitly addressed going to their academic advisors for support during confusing processes such as enrollment. FGCS spoke highly of the type of informational support they received from advisors. Christopher described his interaction with his advisor as follows: "I just didn't really know how to pick the classes, so I sit down with my advisor and told him verbally kind of like what my game plan was, and he kind of broke it down for me." The guidance provided by advisors was mentioned again and again as a source of informational support. Students were not hesitant to lean on advisors and other staff for support. James' story below about one of his discussions with his advisor revealed one point of confusion:

When I was talking to my advisor, I was like, "So am I going to have to enroll into English 101 next semester?" He was like, "No, why would you do that?" I was like, "Well, isn't it a yearlong class?" He's like, "No, it's just a semester class. All your classes are semester classes." I was like, "Really? I did not know that, but okay."

While advisors supported FGCS with enrollment, campus staff supported them in other ways too. For example, financial challenges prompted Ashley to find support from campus staff. Ashley explained that she needed help managing money: "I'm going to the student money management center every month so that ... I have a budget..." Ashely recognized the center as a resource and sought out the expertise of the staff to better manage her own spending. 


\section{Attending to affirmation}

When participants referenced social support from faculty, it was primarily unsolicited appraisal support. Stories within this subtheme emerged when participants were asked about something positive that happened to them. Ashley identified her English professor as a source of appraisal support after she shared progress on a video project: "I played it and she was like, 'This is like the best one in class.' I was just like, 'You're the best person ever for telling me that this is the best one in class,' ... I was pretty excited.”

In addition to appraisal support from instructors, some students mentioned receiving appraisal support from advisors or mentors on campus. Thomas said, "And then my advisor has been really, really helpful ... and she's like, 'Yeah. You're doing great. Keep doing what you're doing."' FGCS felt bolstered by appraisal support regarding academic performance. FGCS always expressed appreciation when hearing positive feedback, demonstrating their value of this support.

FGCS also described their value of affirmations that came from their parents' or grandparents' emotional support of them. Robert stated, "Well, um the pride in it so far is, really is the main thing that's been showing. Coming to [this university], my parents were always like, 'Yeah, well my son goes to [this university],' just kind of boasting." Rebecca also described positive reinforcement from her parents by stating, "They're telling me I'm smart, I can do this, we're so proud.... I'm the only one out of both of my parents' children, I'm the youngest out of six total and the only one getting a degree." Amanda also disclosed, "It does make my family proud, I can tell.... My grandma dropped out of high school. So she's like really pushing me to do my best." Catherine also shared that her "parents are proud." When asked how she thinks her friends and family back home think of her since she started college, Michelle shared the following story:

I think they all look at me a little bit differently now. I know my mom sees me differently and my dad's really proud of me. I called him yesterday after I signed my lease and he told me he was proud of me, and he's never told me that, so it was super important for me to know. I was like, "Okay, I'm doing a good job if my dad's proud of me."

As illustrated, knowing parents and grandparents were proud and encouraging provided important appraisal and emotional support for these participants.

\section{Enacting social support (RQ3)}

Although participants did not describe themselves as being able to fully enact a social support role, they did engage in social support in some ways, and they imagined providing social support to others in the future. Specifically, participants often shared that they imagined and hoped that attending college and earning a degree would ultimately lead to upward mobility, helping them and their families in present and future endeavors. They constructed this social support in two ways: giving back and imagining a different future.

\section{Giving back}

One way participants enacted social support was to provide information about college to family. For instance, Mary called home to inform her parents about the cost of college: 
"Mom, you guys need to start saving. You don't understand. It is really expensive," and once I start talking numbers to them, they're like, it goes right over their head because they can't comprehend that it's so important, but it's so expensive.

Here, Mary provided informational support to her parents, so that her younger siblings' transition to college would not be halted by cost. Rebecca expressed similar ideas when asked how she thought her college education might impact her family, "Um, I will be able to help like for instance my parents. Um, I want ... to give back as much as they've given me. To help them in that way financially ... " Caroline echoed this notion of giving back, stating, "I want to give back to my parents for all they've like done for me and stuff like that, because they've, they've done that for me. So, I want to do the same for them." Similarly, Linda also explained that her parents struggled at times, articulating the desire to give back: "I really wanted to gain financial stability to help my parents out, because I know they struggle to get us through school, you know, they never really took advantage of that."

\section{Imagining a different future}

Another slightly different way FGCS enacted social support was to imagine a different future for themselves and their families. For example, Michelle disclosed, "I plan on getting a better career and maybe even helping [my parents] provide for themselves since they're struggling right now." Jennifer also disclosed a similar expectation,

Well, they never went to college, so they have high expectations from me that I will uh get a good job. ... So, um, I will be able to provide for them since their opportunities are much less than what mine are. So, I think just getting this education and getting the degree will definitely help me, but more than that, help my family.

Future expectations for achieving upward mobility and family were common. Catherine also imagined a different future, articulating that one of the reasons she is majoring in prepharmacy is to be knowledgeable about interactions between pharmaceutical drugs. She explained how she could help her mom who was diagnosed with multiple sclerosis,

I can go to doctor's appointments with my mom, and I can keep track of what she's on and really kind of watch over her and keep her safe. And then also, like when I'm older and a parent, like with my own kids...

Some participants extended their expectation for providing instrumental support beyond parents. For instance, Robert explained his anticipation to provide, "[W]hen I have a family, wife and kids, I can really support them without having to worry about what my next job will be. I'll have a career." Patricia echoed a similar sentiment saying,

Not just for myself, but for my little brothers and if I end up having a family or something like that. I want to be able to take care of them and not struggle as much as my parents did.

Lisa also shared, "I would be able to support them [my future children] better with the college degree than just a high school degree." Caroline also mentioned future children:

I want to make sure my future kids will have everything that they need and more, because I want my kids to have the best of the best. Live in the best house possible, drive the nice, nicest cars possible.

Not only did some FGCS begin to provide social support during their first semester of college, they anticipated a future where they could continue to do so. 


\section{Discussion}

This study coupled together the theoretical frameworks of organizational assimilation and social support in the context of FGCS socialization. By doing this, we describe a complex and potentially powerful explanatory framework for understanding these early stages of FGCS socialization. Although our findings reveal some challenges FGCS need to overcome in their transition to college, they also illustrate the role social support plays to alleviate some uncertainty associated with this turning point. Specifically, this study suggests that FGCS seek out and engage mostly in informational and instrumental support prior to entering school, and while such support is still important in the first semester, so too is emotional and appraisal support. Ultimately, these FGCS-even this early in the college experience-came to embody the role of pioneers and brokers, placing them in an important position to have a considerable impact at home and with their peers.

By exploring the intersections of organizational assimilation and social support frameworks, we were able to further understand the temporal and shifting nature of socially supportive communication processes within the socialization experiences of FGCS. Our findings illuminate the role played by multiple forms of social support in helping students move through the different phases of socialization. Organizational assimilation literature explicitly addresses the way newcomers intentionally and communicatively engage in information-seeking behaviors (Kramer, 2010; Miller \& Jablin, 1991). However, by using social support as an additional theoretical underpinning of this study, we can more clearly articulate the way communication focuses not only on information-seeking, but also on more relational aspects of socialization such as impression management, appraisal, emotional support, and peer interactions. Additionally, we do know from the literature that these relational aspects of the college experience are influenced by racial/ethnic identity characteristics (Bordes \& Arredondo, 2005; Davis et al., 2004; Frank, 2003; Lopez, 1995), and this study becomes a springboard for future research to explore the intersections of these identity characteristics and social support interactions.

Additionally, whereas socialization literature (Jablin, 1987; Kramer, 2010; Miller \& Jablin, 1991) identifies information giving as a communication behavior occurring later in the socialization process, FGCS in our study were enacting social support behaviors (even if only imagined) in the earlier stages, despite the uncertainty that characterizes their experiences during the first semester of college. This shift illustrates a unique onus of responsibility for FGCS, who (as the first individuals to embark upon this new journey) might see themselves as responsible for giving information and support, even though they have not yet reduced their own uncertainty about their distinct experiences as first-generation students. Our findings highlight this perceived communicative responsibility for FGCS, positioning them as pioneers in ways typically expected of those who are further along in the socialization process. Future research could explore the ways in which FGCS enact this pioneering role in later phases of socialization and the communication strategies that characterize parent-student interactions (especially when parents might be experiencing complex emotional responses to their children working toward graduation and potentially changing the trajectory of the family's education). 


\section{Implications for teaching and learning}

The majority of participants mentioned that their high school teachers and counselors helped them with the college application process. However, participants reported they did not know what to expect in terms of the overall structure of college education. For instance, participants did not know one academic year was composed of two or more semesters, with new classes each semester, contrary to their high school experiences with yearlong courses. To reduce confusion and ease this transition, high school teachers and counselors might share their own academic and social college experiences in formal workshops, informing students about what to expect during that first semester of college. High schools could also develop partnerships with local universities to invite current FGCS to share experiences with prospective FGCS. Indeed, given that the FGCS in this study already embodied the pioneer role, they could be (and have been shown to be) important partners in supporting high school efforts to prepare students for college (Swail, 2000).

It is vital that universities continue to provide avenues of support during the encounter phase of FGCS socialization, particularly as students are adjusting to college life. Based on this study, it seems important for FGCS to engage in structures that provide multiple forms of social support and that are sensitive to the phases of socialization. Phased mentorship programs could pair prospective FGCS in high school with first- or second-year FGCS. Subsequently, first- and second-year FGCS could be mentored by third- and fourth-year FGCS, and graduating FGCS mentored by alumni. This would effectively put into practice the pioneering identity that seemed to emerge early in the socialization process with our FGCS participants and may feed their desire to give back.

In addition, there are implications at the university level. Universities should also promote first-generation experiences across campus. For instance, universities could invite first-generation speakers and showcase the accomplishments of first-generation alumni. Deans could encourage their faculty to incorporate first-generation experiences in their curriculum as another aspect of diversity by assigning readings from first-generation authors and discussing first-generation experiences in their field. This could expose FGCS to role models and validate their choice to study a particular major, as participants in this study reported not seeing FGCS in the media and were often the ones acting as role models for younger family members.

There are a number of implications for instructors at the college level, and in particular for teachers and advisors. For teachers, especially those teaching first-year students, providing information to assist in transition could benefit all, but in particular, FGCS. Such information about university services, such as counseling services or writing centers, could open the door for FGCS to seek out social support. Also, given the important role of social support for reducing uncertainty in students in this study, instructors could provide information about how to connect with affinity groups at the college or university level. To this end, instructors may also encourage students to organize study groups or class-based affinity groups that meet regularly to discuss class content, thus integrating social support opportunities into the classroom curriculum. Additionally, teachers could consider assigning readings (where appropriate to the content) from first-generation authors, allowing exposure to role models for FGCS and breaking down stereotypes others might have of FGCS. Finally, while many teachers and advisors focus attention 
primarily on academic performance, more explicit attention to the relational, social, and familial needs of FGCS could be warranted. Understanding the strong sense of familial responsibility that these FGCS had (and others might have) might allow teachers and advisors to better support students' academic and cocurricular experiences at school.

\section{Contributions}

Arguably, social support plays an important role in student retention, as students who do not feel welcome on campus are more likely to drop out, regardless of academic performance. This is especially important for FGCS, who are more likely to feel isolated and to wonder if they belong on campus. The early phases of socialization are critical moments in time, given current attrition rates for FGCS (Postsecondary National Policy Institute, 2016). It is possible that the more sources and types of social support students receive, the more likely they will be to persevere in their postsecondary education. Results from this study provide information that encourages all those who serve in a social support role for FGCS (e.g., high school teachers, counselors, university staff, faculty, and advisors) to attend to various forms of social support during early phases of socialization. In essence, this more holistic view of social support, temporally nuanced based on the phases of socialization, could illuminate possibilities for interacting with FGCS in ways that could increase the likelihood that they will stay in school and improve their overall educational experience.

\section{Notes}

1. We use this conceptualization of FGCS since this is how the institution where recruitment took place defined FGCS. In this definition, if a student's parent started but did not complete college, this student would still be considered first-generation. Many universities use this same conceptualization of FGCS.

2. Our interview protocol was not identity-specific (i.e., it did not explicitly explore distinctions between identity features such as race, class, and first-generation status). Future studies should take this limitation into account and develop different interview guides based on the various self-ascribed identities of FGCS.

3. We recognize our study solely relied on our participants' ability to recall their actions. Future research would benefit from observational data between FGCS and family, peers, faculty, and staff.

4. We interviewed FGCS in November and December 2016, when several racial incidents at various universities were making headlines. While some racial/ethnic minority students did say that it made them think more about their racial/ethnic identity at a predominantly white university, the large majority said they felt welcome at this university. That is, their racial/ethnic identity did not emerge in the data as a dominant factor influencing socialization during their first semester of college.

\section{Acknowledgement}

We are grateful to the first-generation college students who voluntarily shared their stories. We are also appreciative of the mentors, advisors, instructors, and multicultural affairs staff who support FGCS and promoted our research. Finally, we would like to thank Dr. Adrianne Kunkel and Dr. Angie Pastorek for serving as friendly reviewers and peer debriefers throughout the research process. 


\section{Funding}

This work was supported by University of Kansas (Faculty Start Up Funds).

\section{ORCID}

Angela N. Gist-Mackey (D) http://orcid.org/0000-0002-1590-0728

Marissa L. Wiley (D) http://orcid.org/0000-0001-5627-5319

\section{References}

Balemian, K., \& Feng, J. (2013). First generation students: College aspirations, preparedness and challenges. College Board. Retrieved from https://research.collegeboard.org/sites/default/files/ publications/2013/8/presentation-apac-2013-first-generation-college-aspirations-preparednesschallenges.pdf

Bordes, V., \& Arredondo, P. (2005). Mentoring and 1st-year Latina/o college students. Journal of Hispanic Higher Education, 4(2), 114-133.

Braithwaite, D., \& Eckstein, N. (2003). How people with disabilities communicatively manage assistance: Helping as instrumental social support. Journal of Applied Communication Research, 31(1), 1-26. doi:10.1080/00909880305374

Burleson, B. R., \& MacGeorge, E. L. (2002). Supportive communication. In M. L. Knapp \& J. A. Daley (Eds.), Handbook of interpersonal communication (3rd ed., pp. 374-424). Thousand Oaks, CA: Sage.

Cardoza, K. (2016, January 20). First-generation college students are not succeeding in college, and money isn't the problem. The Washington Post. Retrieved from https://www.washingtonpost. com/posteverything/wp/2016/01/20/first-generation-college-students-are-not-succeeding-incollege-and-money-isnt-the-problem/?utm_term $=.98 \mathrm{cc} 17 \mathrm{deed} 3 \mathrm{c}$

Charmaz, K. (2006). Constructing grounded theory: A practical guide through qualitative analysis. Thousand Oaks, CA: Sage Publications.

Clauss-Ehlers, C. S., \& Wibrowski, C. R. (2007). Building educational resilience and social support: The effects of the educational opportunity fund program among first- and second-generation college students. Journal of College Student Development, 48(5), 574-584. doi:10.1353/csd. 2007.0051

Creswell, J. W. (2007). Qualitative inquiry and research design: Choosing among five approaches (2nd ed.). Thousand Oaks, CA: Sage.

Cutrona, C. E. (1996). Social support in couples. Thousand Oaks, CA: Sage.

Davis, M., Dias-Bowie, Y., Greenberg, K., Klukken, G., Pollio, H. R., Thomas, S. P., \& Thompson, C. L. (2004). "A fly in the buttermilk": Descriptions of university life by successful black undergraduate students at a predominantly white southeastern university. Journal of Higher Education, 75(4), 420-445.

Emerson, A. R., Fretz, R. I., \& Shaw, L. L. (1995). Writing ethnographic notes. Chicago, IL: University of Chicago Press.

Farmer-Hinton, R. L., \& Adams, T. L. (2006). Social capital and college preparation: Exploring the role of counselors in a college prep school for black students. Negro Educational Review, 57(1/2), 101-116. 140.

First Generation Foundation. (2013). Retrieved from http://www.firstgenerationfoundation.org/

Fischer, M. J. (2007). Settling into campus life: Differences by race/ethnicity in college involvement and outcomes. Journal of Higher Education, 78(2), 125-161.

Frank, A. M. (2003). If they come, we should listen: African American education majors' perceptions of a predominantly white university experience. Teaching and Teacher Education, 19(7), 697-717.

Ghazzawi, I., \& Jagannathan, C. (2011). Bridging the gap: The role of outreach programs in granting college access to first generation students. Academy of Educational Leadership Journal, 15(1), 117-137. 
Gibbons, M. M., \& Borders, L. D. (2010). Prospective first-generation college students: A social-cognitive perspective. The Career Development Quarterly, 58(3), 194-208. doi:10.1002/j.2161-0045. 2010.tb00186.x

Grant-Vallone, E., Reid, K., Umali, C., \& Pohlert, E. (2003). An analysis of the effects of self-esteem, social support, and participation in student support services on students' adjustment and commitment to college. Journal of College Student Retention, 5(3), 255-274. doi:10.2190/C0T7YX50-F71V-00CW

House, J. (1981). Work stress and social support. Reading, MA: Addison-Wesley.

Inkelas, K. K., Daver, Z. E., Vogt, K. E., \& Leonard, J. B. (2007). Living-learning programs and firstgeneration college students' academic and social transition to college. Research in Higher Education, 48(4), 403-434. doi:10.1007/s11162-006-9031-6

Jablin, F. M. (1987). Organizational entry, assimilation and exit. In F. M. Jablin, L. L. Putnam, K. H. Roberts, \& L. W. Porter (Eds.), Handbook of organizational communication: An interdisciplinary perspective (pp. 679-740). Newbury Park, CA: Sage.

Jablin, F. M. (2001). Organizational entry, assimilation, and disengagement/exit. In F. M. Jablin \& L. L. Putnam (Eds.), The new handbook of organizational communication: Advances in theory, research, and methods (pp. 732-818). Thousand Oaks, CA: Sage. doi:10.4135/9781412986243

Jenkins, S. R., Belanger, A., Connally, M. L., Boals, B., \& Duron, K. M. (2013). First-generation undergraduate students' social support, depression, and life satisfaction. Journal of College Counseling, 16(2), 129-142. doi:10.1002/j.2161-1882.2013.00032.x

Keeter, S., \& Taylor, P. (2009, December 10). The Millennials. Pew Research Center. Retrieved from http://www.pewresearch.org/2009/12/10/the-millennials/

Kinzie, J., Gonyea, R., Shoup, R., \& Kuh, G. D. (2008). Promoting persistence and success of underrepresented students: Lessons for teaching and learning. New Directions for Teaching and Learning, 115, 21-38.

Kramer, M. W. (2010). Organizational socialization: Joining and leaving organizations. Malden, MA: Polity Press.

Kuh, G. D. (1995). The other curriculum: Out-of-class experiences associated with student learning and personal development. Journal of Higher Education, 66, 123-155. doi:10.2307=2943909

Kuh, G. D. (2016). Making learning meaningful: Engaging students in ways that matter to them. New Directions for Teaching and Learning, 145, 49-56.

Kuh, G. D., Kinzie, J., Buckley, J. A., Bridges, B. K., \& Hayek, J. C. (2007). Piecing together the student success puzzle: Research, propositions, and recommendations. ASHE Higher Education Report, 32(5), 1-182.

Lancaster, C. M. (2010). First-generation college students, graduate school, and social support. (Master's thesis). Retrieved from ProQuest Dissertations \& Theses database. UMI No. 1477323.

Leach, M. S., \& Braithwaite, D. O. (1996). A binding tie: Supportive communication of family kinkeepers. Journal of Applied Communication Research, 24, 200-216. doi:10.1080/ 00909889609365451

Lopez, E. M. (1995). Challenges and resources of Mexican American students within the family, peer group, and university: Age and gender patterns. Hispanic Journal of Behavioral Sciences, 17(4), 499-508.

Malecki, C. K., \& Demaray, M. K. (2003). What type of support do they need? Investigating student adjustment as related to emotional, informational, appraisal, and instrumental. Support School Psychology Quarterly, 18(3), 231-252. doi:10.1521/scpq.18.3.231.22576

McKay, V. C., \& Estrella, J. (2008). First-generation student success: The role of faculty interaction in service learning courses. Communication Education, 57(3), 356-372.

McNair, T. B., Albertine, S., Cooper, M. A., McDonald, N., \& Major Jr, T. (2016). Becoming a student-ready college: A new culture of leadership for student success. San Francisco, CA: John Wiley \& Sons.

Miller, V. D., \& Jablin, F. M. (1991). Information seeking during organizational entry: Influences, tactics, and a model of the process. Academy of Management Review, 16, 92-120. doi:10.5465/ AMR.1991.4278997 
Napoli, A. R., \& Wortman, P. M. (1998). Psychosocial factors related to retention and early departure of two-year community college students. Research in Higher Education, 39(4), 419-455.

Nazione, S., LaPlante, C., Smith, S. W., Cornacchione, J., Russell, J., \& Stohl, C. (2011). Memorable messages for navigating college life. Journal of Applied Communication Research, 39(2), 123-143. doi: $10.1080 / 00909882.2011 .556138$

Orbe, M. P., \& Groscurth, C. R. (2004). A co-cultural theoretical analysis of communicating on campus and at home: Exploring the negotiation strategies of first generation college (FGC) students. Qualitative Research Reports in Communication, 5, 41-47.

Orbe, M. P. (1998). Constructing co-cultural theory: An explication of culture, power, and communication. Thousand Oaks, CA: Sage.

Orbe, M. P. (2004). Negotiating multiple identities within multiple frames: An analysis of first-generation college students. Communication Education, 53(2), 131-149. doi:10.1080/ 03634520410001682401

Orbe, M. P. (2008). Theorizing multidimensional identity negotiation: Reflections on the lived experiences of first-generation college students. New Directions for Child and Adolescent Development, 2008(120), 81-95. doi:10.1002/cd.217

Padgett, R. D., Goodman, K. M., Johnson, M. P., Saichaie, K., Umbach, P. D., \& Pascarella, E. T. (2010). The impact of college student socialization, social class, and race on need for cognition. New Directions for Institutional Research, 145, 99-111.

Pike, G. R., \& Kuh, G. D. (2005). First-and second-generation college students: A comparison of their engagement and intellectual development. The Journal of Higher Education, 76(3), 276-300.

Pike, G. R., Kuh, G. D., \& McCormick, A. C. (2011). An investigation of the contingent relationships between learning community participation and student engagement. Research in Higher Education, 52(3), 300-322.

Postsecondary National Policy Institute. (2016). Facts and figures related to first-generation students in higher education. Retrieved from https://pnpi.org/factsheets/first-generation-students/

Purswell, K. E., Yazedjian, A., \& Toews, M. L. (2009). Students' intentions and social support as predictors of self-reported academic behaviors: A comparison of first- and continuing-generation college students. Journal of College Student Retention, 10(2), 191-206. doi:10.2190/CS.10. 2.e

Sidelinger, R. J., Bolen, D. M., McMullen, A. L., \& Nyeste, M. C. (2015). Academic and social integration in the basic communication course: Predictors of students' out-of-class communication and academic learning. Communication Studies, 66(1), 63-84.

Staton, A. Q. (1990). Communication and student socialization. Norwood, NJ: Ablex Publishing Corporation.

Stephan, J. L., \& Rosenbaum, J. E. (2013). Can high schools reduce college enrollment gaps with a new counseling model? Educational Evaluation and Policy Analysis, 35(2), 200-219.

Swail, W. S. (2000). Preparing America's disadvantaged for college: Programs that increase college opportunity. New Directions for Institutional Research, 2000(107), 85-101. doi:10.1002/ir.10706

Thompson, B. (2008). How college freshmen communicate student academic support: A grounded theory study. Communication Education, 57(1), 123-144.

Tracy, S. J. (2010). Qualitative quality: Eight "big-tent" criteria for excellent qualitative research. Qualitative Inquiry, 16(10), 837-851.

U.S. Department of Education. (2015). Percentage of undergraduates receiving financial aid, by type and source of aid and selected student characteristics: 2011-12. Retrieved from: https://nces.ed. gov/programs/digest/d15/tables/dt15_331.10.asp

U.S. Department of Education. (2016a). Percentage of 18- to 24-year-olds enrolled in degree-granting postsecondary institutions, by level of institution and sex and race/ethnicity of student: 1970 through 2015. Retrieved from https://nces.ed.gov/programs/digest/d16/tables/dt16_302.60.asp

U.S. Department of Education. (2016b). Graduation rate from first institution attended for firsttime, full-time bachelor's degree- seeking students at 4-year postsecondary institutions, by race/ethnicity, time to completion, sex, control of institution, and acceptance rate: Selected cohort entry years, 1996 through 2009. Retrieved from https:/nces.ed.gov/programs/digest/ d16/tables/dt16_326.10.asp 
Wang, T. R. (2014). Formational turning points in the transition to college: Understanding how communication events shape first-generation students' pedagogical and interpersonal relationships with their college teachers. Communication Education, 63(1), 63-82.

Wasburn-Moses, L. (2007). Minority students' perceptions of their doctoral programs in special education. Journal of Teacher Education, 58(5), 456-469.

Weick, K. E. (1995). Sensemaking in organizations. Thousand Oaks, CA: Sage.

\section{Appendix A}

Table 1. Participants' demographic characteristics.

\begin{tabular}{|c|c|c|c|c|}
\hline Pseudonym & Race/ethnicity $^{1}$ & Major $^{1}$ & Parents' education & Parents' occupation ${ }^{1}$ \\
\hline Amanda & Mexican & PreNursing & High School Diploma & Works at Kellogg's-Unemployed \\
\hline Anthony & Mexican/Chicano & Microbiology & Some High School & Chef-Housewife \\
\hline Ashley & Black & International Studies & Some College & Budget Analysis for State \\
\hline Barbara & Haitian & Psychology & High School Diploma & Chef \\
\hline Brian & Asian & Exercise Science & Elementary & Nail Salon-Homemaker \\
\hline Caroline & Black & Marketing & Some College & Marketing-Accounting \\
\hline Catherine & Caucasian & PrePharmacy & High School Diploma & $\begin{array}{l}\text { Supervisor for Post Office-Lowe's } \\
\text { cashier }\end{array}$ \\
\hline Christopher & White & Sociology & Some High School & Firefighter-Special Education Para \\
\hline David & Latino/Hispanic & Biology & Some High School & Owns and Operates a Restaurant \\
\hline Donald & Hispanic & Electrical Engineering & $\begin{array}{l}\text { Elementary-High } \\
\text { School Diploma }\end{array}$ & Landscaper-Insurance Adjuster \\
\hline James & African & $\begin{array}{l}\text { Aerospace } \\
\text { Engineering }\end{array}$ & Some College & Licensed Practical Nurse \\
\hline Jennifer & Asian & PreBusiness & Some High School & Manager \\
\hline Jessica & Hispanic & $\begin{array}{l}\text { Latin American } \\
\text { Studies }\end{array}$ & High School Diploma & $\begin{array}{l}\text { Mail room-Dept. of Procurement } \\
\text { Services }\end{array}$ \\
\hline John & African American & Communication & High School Diploma & Water Plant-School Counselor \\
\hline Kevin & Black & Athletic Training & Some College & Truck Driver-Teacher \\
\hline Linda & Black & $\begin{array}{l}\text { Petroleum } \\
\text { Engineering }\end{array}$ & Some College & Chemical Plant \\
\hline Lisa & Mexican & PrePharmacy & $\begin{array}{l}\text { Some High School- } \\
\text { High School } \\
\text { Diploma }\end{array}$ & Business Owner-Family Advocate \\
\hline Mark & Hispanic & Pharmacy & Some High School & Landscaping-Kitchen Manager \\
\hline Mary & Hispanic & Community Health & Some High School & Construction-Housewife \\
\hline Matthew & African American & Engineering & $\begin{array}{l}\text { High School Diploma } \\
\text { —Some College }\end{array}$ & Airport employee \\
\hline Michelle & Caucasian & Journalism & High School Diploma & Midwest Freight—Retail \\
\hline Patricia & Latino/Hispanic & $\begin{array}{l}\text { English and Women's } \\
\text { Studies }\end{array}$ & Some College & Unemployed-Real Estate \\
\hline Paul & Hispanic & Entrepreneurship & High School Diploma & Post Office \\
\hline Rebecca & Hispanic/Latina & Psychology & High School Diploma & $\begin{array}{l}\text { Owner of semitruck-Greeter at } \\
\text { bank }\end{array}$ \\
\hline Richard & Asian & Civil Engineering & Some College & Navy_-Board of Education \\
\hline Robert & Puerto Rican/Latino & Sports Medicine & Some High School & Car Salesman-Phlebotomist \\
\hline Stephanie & African American & Exercise Science & Some High School & $\begin{array}{l}\text { Owns Barbershop-In home } \\
\text { healthcare }\end{array}$ \\
\hline Thomas & White & $\begin{array}{l}\text { Strategic } \\
\quad \text { Communications }\end{array}$ & High School Diploma & $\begin{array}{l}\text { Target Distribution Center-State } \\
\text { Tax Revenue }\end{array}$ \\
\hline
\end{tabular}

\footnotetext{
${ }^{1}$ Participants answered these questions in their own words.
} 